\title{
Civil Economy in the Social Market Economy: a Theoretical Perspective
}

Flavio Felice*

University of Molise, Campobasso, Italy

Received November 13 2017; Accepted December 92017

Abstract: What do we mean by "civil" and "civil society"? This paper attempts to describe a complex notion of "civil economy" in Sturzo's theoretical perspective of the social market economy. According to this political theory, "civil" is not opposed to "market," which is not opposed to "the political" (the state). Rather, instead of being the transmission belt between the state and market, civil is the galaxy in which we find also the market and the state (but not only), each with its own functions. This tradition - rooted in Christianity - was able to oppose both Nazi and communist totalitarianism, while many Catholics made an impossible attempt to exhume corporatism.

Keywords: Civil society • Social market economy • Luigi Sturzo • Polyarchy

\section{Introduction}

This paper attempts to explain how the model of the social market economy (SME) may represent a theoretical perspective for a notion of "civil economy" (Felice 2008). The author emphasizes that neither the civil society can be identified as the transmission belt between the state and the market nor the market can be considered its alternative.

The author would like to present a problematic situation that follows from Popper's critique to Plato's question, "who should rule?" (Paragraph 1). The author also would like to discuss the offhand - and even superficial use of "civil society" (Paragraph 2) rediscovering the peculiar interpretation given by the Italian political scientist, Sturzo ${ }^{1}$ (Paragraph 3). Sturzo was a prominent European figure within sociological, political, and economic thought; he was strictly in touch with the father

1 About Sturzo's life and works, see De Rosa (1977), Di Lascia (1945), Pollock (1953), Timasheff (1962), Antonetti (2017). of SME, the economist Wilhelm Röpke, and one of the most important political interpreters of this theoretical perspective, the Chancellor Konrad Adenauer: "Germany, however, has a great place, and perhaps so far underestimated emphasis, on Sturzo's thought" (Liermann 2004, p.255). Sturzo's popolarismo not only was rooted in Catholic social thought but also developed and spread the principles and values of SME in Italian academic and political realms (Paragraph 4).

\section{Who should rule?}

One of the most overused questions in the history of political thought is "who should rule?" Popper devoted several pages of The Open Society and Its Enemies to this question. This Viennese philosopher's argument was that Plato corrupted Western political theory with that question: "It is my conviction that by expressing the problem of politics in the form 'Who should rule?' or 'Whose will should be supreme?', etc., Plato created a 
lasting confusion in political philosophy" (Popper 1966, p.125; see also Shearmur 1996; Antiseri 2000, 2011; Di lorio 2015; Di Nuoscio in press).

Plato's response to his question indicated the category to which he belonged, the philosophers. However, Popper critically commented, "But such a reply, convincing as it may sound - for who would advocate the rule worst or 'the greatest fool' or 'the born slave'? - is, as I shall try to show, quite useless" (Popper 1966, p.125). After Plato, several political theorists have argued for governance by a divine lineage of kings, a king by the grace of God, and the will of the nation as well as a king for the nation's will. Others have also argued for governance by the majority, the best people or the best man, a prince or an armed prince, the religious class, the industrial leaders, and the economic-political technicians. In the past century, several thinkers hold it would have to govern the Aryan race or the proletarian class (Antiseri 2011). Two answers, Dario Antiseri glosses: the first Nazi, the second communist, which are hung millions and millions of victims sacrificed on the altar of crazy and cruel theories. ${ }^{2}$

Although the question may appear acceptable, according to Popper, it is irrational, as it invites us to seek what does not exist: a figure, class, group, or race, capable by nature and, therefore, called by fate or by providence to rule over others. Popper showed a remarkable convergence with the idea of political authority developed by Sturzo in The Inner Laws of Society ${ }^{3}$ (Suppa 2004) when he stated that it is this authority substance that does not exist in any class, group, or race: there is no individual, group, or category that has come into the world with the predicate, or attribute, of domination on others. ${ }^{4}$

\section{What is civil society?}

The crisis of politics emphasized by many financial scandals and corruption cases prompted a reply to Plato's

2 Antiseri (2000, pp.393-396).

3 "The metaphor of the open society, therefore, represents an exact opposite of that of organicism. Even if the expression invites us to think of the famous framework of philosopher Popper, we speak of a different reasoning, of renewed intellectual relevance. Here, in Sturzo, it is not just a matter of combating a philosophy of history, suffering from deterministic and unjustified pretense of predicting the future; the open society in Sturzo alludes to a dynamic society, which knows the reasons for the push, but not its outcomes" (Suppa 2004, p.727).

4 "I shall call this assumption the theory of (unchecked) sovereignty, using this expression not for any particular one of the various theories of sovereignty, proffered more especially by such writers as Bodin, Rousseau, or Hegel, but for the more general assumption that political power is practically unchecked, or for the demand that it ought to be so; together with the implication that the main question left is to get this power into the best hands" (Popper 1966, p.126). question, holding that a more civil society role should be recognized. However, what is civil society in which everyone takes refuge? Moreover, would not it run the risk of providing an ambiguous answer to a senseless question?

According to Edwards, civil society is one of the most enduring and confusing notions in social science. He stated, "The concept is enduring because offers a malleable framework through which to examine the 'geometry of human relations', [...] the patterns of collective action and interaction that provide societies with at least partial answers to questions of structure and authority, meaning and belonging, citizenship and self-direction" (Edwards 2011, p.3). On the other hand, Walzer defined civil society as the sphere of "uncoerced human association" between the individual and the state, in which people undertake collective action for normative and substantive purposes, relatively independent of the government and market (Walzer 1998, pp.123-124). The definitions of terms - coercion, independence, norms, and purposes - are matter of "continued and necessary debate" (Edwards 2011, p.4). In any case, Greek and Roman traditions conceived civility as an orientation toward the common good and a necessary requirement of effective citizenship. Thus, the civil society is associated with political commonwealth. Greek and Roman thinkers also allowed us to understand that "life is lived in different spheres that have their own internal logic" and it "drove toward a more nuanced approach that made possible a recognition of social complexity and the limits of political life" (Ehrenberg 2011, p.15).

In particular, if we consider the Aristotelian sense of the term "civil," we link it to polis, which, in other words, is koinonía politiké, the community politically constituted, in its highest authority that informs the constitution and politics of all societies (Koslowski 1976): a standardized and exclusive system of civic values, where the political dimension takes precedence over others. From Aristotle to the Italian Renaissance (Koslowski 1997), the societas civilis sive politica is synonymous with organic society capable of civilization (Donati 1997).

As per the Romans, civil refers to cives and civitas, a membership to a community by virtue of law. Ricci summarized a peculiar characteristic of Roman civitas, "If the Wells' car of time transferred a resident of Rome at the August era to the contemporary metropolis, the traveller would be astonished at all except in the wonders of the faces, clothing, religious practices and languages of its inhabitants, which is commonplace today. Near the river, not far from the sea, easily reachable, the original Rome was well visible and therefore attended by neighbouring peoples, always accustomed to diversity and multiple attendance, such as all the major ports 
and major cities of the world" (Ricci 2017, p.140; see also Todisco 2017, pp.154-157). The Roman politician, Cicero, considered civil society as a set of public powers whose organization made civilization possible where the organizing principle is justice.

According to St. Thomas, civil is an organic whole that responds to natural law. The principle of totality is interpreted organically, wherein the resulting empowerment of personality involves living virtuously. In Thomas's thought, the polis is a "finalistic whole," which is organized for the common good. Therefore, polis, among communities, is the most important as it contains, encloses, and defends the most important goods of humanity "We can therefore say that the city is the context in which man can practice virtue and therefore cultivate one's own humanity. It is the only area where this can fully happen. The city is not therefore, only a set of men, but also a dimension of the human spirit" (Buttiglione 1985, p.26). In this paper, the term "political" refers to the social body oriented toward the common good and the civil is the state-city, the polis, which is distinguished by the absence of Barbarians, who live outside (Donati 1997).

Hobbes introduced the monstrous notion of civil that demands the intervention of Leviathan to avoid the war of all against all. Although modernity was defined by the idea that civic institutions shape a vigorous public life and that creative leadership and "good laws" are able to mitigate inevitable disputes and class conflict that arise from the "natural condition of humankind," Thomas Hobbes affirmed the following: "In a word that was being defined by the religious claims of the individual conscience and the pursuit of private interest, only state power can make civilization possible" (Ehrenberg 2011, p.18). This means that domestic peace requires the strongest possible presence of the "artificial man" who makes it possible for the "real man" to live "free of a constant threat of annihilation." Therefore, according to Hobbes, civil society is made possible by sovereign power and is performed by politics, which perfectly coincides with the state. Successively, John Locke and Adam Smith declined the concept of civil in the market. According to Ehrenberg, they elaborated the presence of a modern theory of civil society populated by economic persons, where the state exists to protect the rights of acquisition and accumulation, reflecting a rule of law, where the state's duty is to protect the structured economic life of self-interested members.

The Anglo-Saxon model views civil society as a set of nonpolitical relationships of exchange between people, where the fundamental ideal is individual freedom (Donati 1997). In this view, citizenship is found on property rights and the state exists to protect them.
The notion of civil society is thus it enters a new territory: market processes based on a set of "prepolitical natural rights." The market was considered an arena where honest people are confronted and a social arena formed by people who act "with a deep personal conscience, following the rules of honesty, mutual trust, respect for contracts, equivalence criteria. The central idea is the exchange arena (that of civil society) is rooted in a sphere of values based on the reciprocity of individual recognition, according to an intimate human propensity" (Donati 1997, p.40). This model presents many variants, ranging from Adam Ferguson's and Adam Smith's evolutionary tradition to the Austrian School and Popper's "open society." Social institutions are conceived as the unintended fruit of human voluntary actions. By contrast, John Locke argued for a contractual tradition where the society is conceived as a result of a pact. However, both schools of thought shared the idea that "the activities of people in markets, rather than in politics, are the real glue of civil society" (Ehrenberg 2011, p.21).

Hegel expressed a moment of the dialectic that materializes itself in the state. As Donati observed, "Hegel resumes the Anglo-Saxon meaning of civil society by identifying it ipso facto with the market, on the basis of a precise lifestyle, the bourgeoisie" (Donati 1997, p.40). In this paper, however, the market is considered a "moment" in a dialectical process that has the state at the center "the principle governing relations between civil society, namely political society, and other pre-political societies is the principle of subsumption or Aufhebubg: pre-political communities don't find there raison d'être into themselves, but they are sublated, ultimately, they are abolished into civil society" (Koslowski 1997, p.47). Civil society is mercantile by its very nature, but it supports an ethics that is only universalized by politicizing itself in the state. In this sense, Hegel's vision represents a sui generis synthesis between the Anglo-Saxon model of civil society as a market and as political society, in the twofold classical (Aristotelian) and modern (Jacobin) version of "general will" (Donati 1997). This means that Hegel shared Smith's perspective, wherein civil society is performed by economic processes. However, Hegel did not share Smith's optimistic idea that the "common good" can derive from private expectations. Hegel maintained that, even if civil society is a moment in moral freedom, it is a limited and dangerous one, "because it drives toward making itself the only determination for social life." It led Hegel "to look into the universal state to transcend the limits of the "system of needs"” (Ehrenberg 2011, p.22).

On the other hand, Marx thought that the "civil" is the representation of bourgeois pretension that will be wiped out by the proletariat's inescapable grip of class 
consciousness: the working class, through the party, will conclude the course of history, establishing communism. According to Ehrenberg, Marx's early work led him to conclude that "Hegel's state was a false universal that could not be the final moment in human freedom" (Ehrenberg 2011, p.22). Although he was right about the contribution of "the great bourgeois revolution" to free the state from the "formal constraints" of civil society, he failed or underestimated the implications of their freeing society from the state, "if public life now functioned in formal separation from feudal determinations of property, religion, class, and the like, it was no less true that property, religion, and class were now free to develop in formal isolation from political determinations and constraints" (Ehrenberg 2011, p.22). If Hegel theorized the state as freedom from social antagonisms in terms of civil society, Marx's critique of the state can be considered part of a larger critique of civil society to be transcended. Thus, the proletariat becomes the alternative to Hegel's state "Marx looked at the constitute processes of civil society itself and found the universal class there, in the person of the property-less proletariat [...] Democratizing civil society requires abolishing it and moving toward an 'association' that transcends the chaos, antagonism, inequality, and arbitrariness of market process" (Ehrenberg 2011, p.23).

Tocqueville, Antonio Rosmini, Sturzo, and others introduced a different understanding of civil. Ehrenberg noted that Tocqueville considered civil society as the network of free associations in which voluntary activity is able to serve the common good: "Echoing James Madison, he hoped that civil society would serve liberty by diluting the influence of any single interest, weakening the majority, and guarding against excess" (Ehrenberg 2011, p.24). Tocqueville's notion of civil society is an attempt to defend freedom from equality and equality from privilege, through freedom (Tocqueville 1969, Vol. I, Intr., p.9).

Thus, the great enemy of democracy for Tocqueville is the absence of social mobility, which appears to be essential to humanity when the dogma of equality and popular sovereignty is assumed (Tocqueville 1969, I, II, X). Although it may take on the character of social conflict, it involves power attained through a regulated competitive process. Tocqueville's idea of competitive political participation shows dynamism in addressing the issue of substantial-formal democratic dichotomy that includes values of participation, freedom, and equality. In this sense, democratic inclusion, on the one hand, uses Dahl's (1971) concept of "degrees of inclusion" and, on the other hand, it attempts to overcome it in its definition as a way of sharing, participating, and moving from a foreign and disadvantaged subject to an integrated and active subject. In practice, it means changing from being a subject to a sovereign citizen and (at this level of discussion) it operates in institutions, their roles, and quality.

This begs the question: What idea of civil do we refer when we claim a greater involvement of civil society? Aristotelian? Then, we should accept a hierarchical scale with politics at the summit. St. Thomas? Then, it poses the problematic relationship with corporatism. Since we exclude Hobbes, Hegel, and Marx for obvious reasons, Locke's, Smith's, and Tocqueville's conceptualizations remain. However, for them, civil is expressed by the order of market and it is not logical to consider the market and civil society as alternatives.

This pedantic survey we believe is necessary to express the difficulty of handling an expression so polysemic - civil and civil economy - especially today, when according to Gramsci's idea, civil society is often identified with those organizations that, being outside the political system, give consent to the establishment of a new political hegemony. Donati stated the following point as well: "Behind all this, it is revealed a civil society as intricate of struggling groups. At best, groups that carry limited spurious interests and identities limited to single issues that claim to be useful and/or valid for everyone. At worst, we are faced with a civil society that, though no longer coincides with that of Marx, made of exploitative capitalists, it's composed by gangs and rival factions, one against the other. Gangs and factions in which premodern loyalties (patronage and affiliation) mingle with the economic interests of a market, to a large extent, capitalist only by name (being, indeed, largely intertwined with subsidies, facilitations and state aids of all kinds)" (Donati 1997, p.26).

\section{Sturzo's civil society}

An interesting interpretation of the notion of civil was offered by Sturzo: ${ }^{5}$ civil is the set of primary and secondary social forms that interfere with each other, "From historical, experimental reality, we find three forms fundamental to social life, answering the requirements of human nature in its three permanent aspects: its affectivity and continuity (the family), the guaranteeing of order and defense (political society), its ethical and finalistic principles (religion)" (Sturzo 1944, p.25). These primary forms for Sturzo are family, religion, and politics, and among the secondary (not in terms of importance, but because they cross the primaries) he highlighted the international community and the economy. This implies

5 "In this respect, it becomes understandable that civil society, according to Sturzo, is above all a project of action" (Pastori 2004, p.772). 
that the question of the civil cannot be solved in its political form, but remains a plural entity, a polyarchic reality (indeed, Sturzo used the expression plurarchia) irreducible to any social form that is not the person. It plays the role of a critical bulwark against the omnivorous claims of those in power; according to Vasale: civil society as "politically organized people" (Vasale 1975, p.431), that sphere of private life, in the sense of a set of rights and duties (Pastori 2004, 824), answerable to the inner forum that "coincides with the individual, individually understood, and hence with its moral sphere dialectically opposed to the public sphere of politics in general, and of the state in particular" (Vasale 1988, p.433). That is, civil society explains a plural notion of society, a polyarchic idea that is not anarchical, because it is organic and ordered through the principle of subsidiarity with a button-up logic and space for resistance (Cappellano 2013).

According to the political theory developed by Sturzo (1944), civil is not opposed to the market, which is not opposed to the political (the state). Civil is the galaxy in which we find the market and the state, each with its own functions. We do not have society, but societies, as a concrete expression of a historical process in the framework of a multiplicity of relationships. In Sturzo's thought, civil society is studied as a datum of the individual conscience, a way to recognize oneself, to know oneself in a self-reflective way (Cappellano 2013), "In the differentiation of his own society from every other, that is, in the group consciousness and in its unity, the individual feels not the suppression of his own personality, but its projection, reflection, enlargement; likewise, the true nature of human society shows itself when it helps to maintain, broaden, raise and perfect the personality of each member" (Sturzo 1944, p.20). Such a peculiar version of methodological individualism ${ }^{6}$ that we prefer to call methodological personalism is clarified in the following: "From the individual - who, it is well to repeat, is the whole of human nature in the concrete proceeds also the ethico-organic element which specifically constitutes society, whether it is the social purpose, which is the same as the inner purpose of the individual carried on to the associative plane, or the coordination of the various individual activities, which is the typical function of human groups. We speak of this element as ethico-organic, so as to affirm that every social form is in itself of a finalistic character and, therefore, ethical, and also so as to distinguish the organization we hold to be an outcome of individual activities from that which the organicist sociologists conceive of as an original,

6 To be more precise, I would use the expression "methodological personalism" (Felice 2001). self-subsistent entity" (Sturzo 1944, p.xvii). The final basis of social fact has to be researched only in the human being, in his/her concreteness, complexity, and insolvability. ${ }^{7}$

The theoretical perspective within the field of economics that has sought to embody Sturzo's idea of civil is the SME and is based on three principles:

1. The polyarchic dimension of civil society and the consequent common good (irreducible to the political dimension) consider competition as a hermeneutic principle and a factor of the common good that deserves to be defended and promoted by an economic constitution.

2. The principle of subsidiarity as a principle of order in horizontal and vertical dimensions assumes that competition of ideas, desires, and projects produces an order that, in their entirety, would not be accessible to the individual or institution. It follows that through such a political adaptation, economic and legal information cannot be obtained by central management, but is the by-product of a process that contributes knowledge of the problem to individuals and institutions.

3. The rejection of political discretion in the organization of the market (economic constitution) deals with the classical ordoliberal idea that "the economic constitution must be understood as a general policy decision on how the economic life of the nation is to be structured" (Böhm et al. 1936, p.24).

In practice, the economic constitution is responsible for defining the line between unfair and appropriate competition and to determine whether free competition exists, whether competition is restricted, whether competition is efficient or creates obstacles, and whether price reductions are according to the free market system.

It deals also with Sturzo's interpretation of state interventionism - that he called "statism" - and his distinction between state interventions in conformity with the market, against state interventions not in conformity and for this reason defined as one of the three "evil beasts" of democracy: "statism," because against the value of freedom; "particracy," because against the value of equality; "waste of public money," because against the value of justice.

All the three principles enhance the civil dimension according to Sturzo, in which the SME theory preserves and upgrades (Forte et al. 2012). It is an Italian, German, European, and Christian tradition that was able to

7 "To our mind, it is the individual consciousness alone, that is, rational man, that effectually resolves into itself every social form, and which in its autonomy unifies all the various elements of human sociality. It grades the ends of the various social forms within which it unfolds its activity, since metaphysically it is the term and the end of society" (Sturzo 1944, p.55). 
oppose Nazi and communist totalitarianism, while many Catholics (nor Sturzo neither Luigi Einaudi) lingered in the impossible attempt to exhume corporatism. They did so precisely so that the civil dimension amounts to the political dimension, which is homogenized by the subject, who, by definition, lays claim to being a "synthetic summit," the state.

This would be the death of the civil, which is why SME's theoretical perspective expresses a relentless defense of the civil against the omnivorous claims of the political. The distinction-separation between state, market, and civil society does not contribute to a realistic analysis of social phenomena or to the analysis of the consequent distinction between public economy (a), market economy $(b)$, and civil economy $(c)$.

In our opinion, rather than considering civil economy as separate and different from the market economy, it would be more useful to use a distinction between a state economy (a') that is necessarily monopolistic, an unregulated private economy ( $\left.b^{\prime}\right)$ that also tends to oligopoly, and a market economy ( $\left.c^{\prime}\right)$ where the state sets the rules of competition punishing those who claim to play without competitors. Under the SME theory, the latter can be termed SME or civil economy to distinguish it from the private but unregulated market, which produces concentrated, oligopolistic, and corporatist tendencies.

\section{Sturzo and the SME}

The application of ordoliberal theories in Italy is very recent and somewhat indirect (Forte and Felice 2016). However, we must acknowledge that the work of authors such as Erhard, Eucken, and Röpke has profoundly influenced broad sectors of Italy's economic and political culture. With regard to liberal popularism, we maintain that Sturzo - a priest, scientist, politician, and statesman - knew how to clearly express social philosophy of these authors. ${ }^{8}$ A significant testimony is a letter sent by the German Chancellor Konrad Adenauer to Palladino on September 25, 1959, a few days after the death of the Sicilian priest, "I esteemed Fr. Sturzo as one of the great politicians, who, out of a profoundly felt sense of Christian responsibility after the chaos of the last war, have worked in every sense to build a new Europe; I hope greatly that Fr. Sturzo's prayers may help me to cooperate, in turn, in the spirit that animated his intention, to resolve the problems that will present

8 "The priest of Caltagirone shared the statements of the German economist Wilhelm Röpke for whom philosophical liberalism was an unconscious asset of Christian tradition; the connection was given by the integral humanism of Maritain that indicated the defence of the human person as a principle against statism and the monopolistic degenerations of capitalism" (Efficace 2004, p.545). themselves for the Christian West" (Palladino 1995, p.53). Having returned to Italy in 1946, after a long and sorrowful exile that began in 1924 (first to France, then to England, and finally to the USA; Farrell-Vinay 2004), Sturzo began working intensely as a freelance journalist for newspapers and academic journals. He was very critical of the growing statist climate of those years that eventually translated into government and parliamentary orientations to the state's intervention in the economy.

In Paura della libertà (Fear of Freedom), dated December 29, 1957, Sturzo wrote that "unfortunately there exists among us, like it or not, a hybrid industrial business, [comprising] the staticized one and the private one; the former with monopolistic privileges, ample state guarantees, a facility of means, and no sense of risk; the latter with a longstanding tradition of state-given favors, facility of means and with a sense of risk; even industrial operators who seek particular favors lose sight of the value of economic freedom and the real interests of national productivity" (Sturzo 1957-1998a, p.158). These are not the words of an impenitent libertarian or an anarcho-capitalist who dreamed of strategies to privatize lunar real estate; rather, these are the words of the father of Italian and European political Catholicism, one of the greatest interpreters of modern Christian social thought and one of the most authoritative social scientists of the 20th century.

This paper is of considerable importance. It is interesting to note how Sturzo affirmed that no form of solidarity appears practicable in the case of coexisting statism and market economy, while a policy oriented toward solidarity would be possible only where a free market exists alongside a state policy of cooperation and intervention that is occasional and more or less agreed upon. These circumstances allow for fair and healthy policy. Ultimately, Sturzo qualified his political-economic position with characteristics typical of the SME. It is not by chance that uses the German and US economic-entrepreneurial reality as an example nor is it by chance that Röpke indicated Sturzo's work as one of his inexhaustible sources of inspiration. Sturzo's SME considers three conceptual elements. First, freedom is unique and individual, "one loses political and cultural freedom if one loses economic freedom, and vice versa," contrary to the Crocian "liberist/liberalistic" distinction and in agreement with the unitary perspective of Einaudi, Hayek, and Röpke. Second, freedom is an expression of self-discipline and legislative regulation, "for the coexistence and respect of reciprocal rights and duties." Third, the main functions of the state are to "guarantee and safeguard collective and private rights," keep public order, assure national defense, safeguard the monetary and credit system, maintain vigilance and 
care for public finance, and guarantee its proper administration. Only secondarily and "subordinately does the state intervene, in a supplementary manner, in those sectors of social and general interest where private initiative is deficient, until these are able to resume their role." As evident, Sturzo, just like the ordoliberals and the fathers of the SME, did not deny that in the cases of necessity the state has to intervene; however, he circumscribed such cases to emergency situations that are for a temporary period and are executed "in a secondary and alternative manner."

The economic freedom that Sturzo referred to "is an economic freedom that conditions and facilitates the existence and development of the political and moral freedoms." In this sense, for Sturzo, "corporativistic illusions" of the "philo-fascist Catholics" of yesterday would collapse. Corporatism, for our author, did not and could not have any realization except in the Mussolinian attempt to identify "state-party-corporation" in the realization of the fascist motto, "all in the state, of the state, for the state, nothing outside the state."

Similarly, economic freedom is linked to the existence and development of political and moral freedoms, which are integral and indivisible freedoms. They allegedly cause the collapse of illusions regarding the "socialist and classist state." The experiences of the Soviet bloc and its satellite countries, as well as of the "forgeries of Belgrade and Beijing," demonstrate that, in the absence of economic freedom, free capitalism is soon substituted by a "state capitalism, a thousand times worse than the private one" and that dictatorship of the proletariat would be nothing but "military dictatorship with the apparatus of profiteering functionalism."

Sturzo, reflecting on these observations, affirmed that "Western countries, more or less individualistic and dynamic, with so many differences of climate, productivity, economic development, customs, needs, history, and culture, and whose political conditions are full of contrasts, will never undergo - except by force - the suppression of their fundamental liberties, of which the economy is the necessary condition" (Sturzo 19571998a, p.158). Although state intervention of Sturzo's time was generally more extensive than it previously was, it had less impact and the private sector's productive energies represented an antidote against state interference in countries with a more solid political

9 On the contrary, it is precisely by recovering the experiences in the 19th-century Social Catholicism that Sturzo developed a sensitivity toward the underlying human factors of the production process, proposing representation for work, understood in its most varied forms, within the administrative organization of the Italian state (Secco Suardo 1962, p.212; Sturzo 1970b, p.147; Sturzo 1970a, pp.103-118). structure and healthier industry. Concerning the case of Italy, Sturzo recognized an inconsistent and immature politics and a weak economic-productive system, wherein responsibilities were constantly withdrawn by state interventionism that assured monopolistic privileges (state guarantees). Consequently, the economic operators were not exposed to the "risk that educates," that is the risk of the failure of the economic initiatives.

In highlighting the fact that state interventionism does not lead to policies of solidarity and respect for personal freedoms, but rather to overcoming an authoritarian sense of free society, Sturzo presented a realistic picture of state intervention's impact. His harsh critique of this reality was extended to the Catholic political and intellectual class who were accustomed to use terms such as "personalism" and "solidarism" as picklocks that would have substituted the typical institutions of the market economy in a sort of new Italian economic model. This was an illusory alternative to the market economy that pervaded political and cultural liberties; illusory because, according to Sturzo, freedom is "individual" and consequently "whole and indivisible" (Sturzo 1957-1998a, p.159).

State intervention, in which Sturzo considered necessary for civil living (living in conformity, according to SME terminology), slips dangerously into statist interventionism: not in conformity, "a destroyer of every institutional order and every administrative order," when it appears as the "systematic degeneration of state intervention, in fields not its own or by provisions harmful to the rights of citizens" (Sturzo 1959-1998b, p.371). An intervention is illegitimate, harmful to the rights of citizens, or "not in conformity with the market economy" (according to Röpke and interpreters of the Freiburg School) when the state does not limit itself to attempting to neutralize hostile factors in joint activities between entrepreneurs and workers; it is legitimate when, ultimately, its action does not extend beyond its particular field, given by the respect for individual freedom, that whole and indivisible freedom of the human person, and given by the historical experience of its concrete applications. The degeneration of statism would result in the monopolization of national capital, consequently contracting productivity, devaluating currency, generalizing functionalism, and effecting a totalitarian drift. As one can see, for Sturzo, the state was, in its very essence, the political form of civil society, analogous to what the Res publica was for the ancient Romans and what the Administration was for the Anglo-Saxons, which, according to Sturzo, is the "power and the administration of the common good."

Anti-statism of a certain tradition of Catholic social thought (following Sturzo's thought) was explained by 
the priest of Caltagirone when he affirmed that statism unhinges the intermediated articulation of society; by centralizing power in the hands of state entities and bureaucratizing civil society, it contravenes one of the cardinal points of the modern social doctrine of the Church: the principle of subsidiarity, both in its horizontal and vertical dimensions. ${ }^{10}$ It weakens a certain capacity for individual resistance in the face of threat of invasion by bureaucratic bodies in the spontaneous life of social organizations. It transforms parties and unions into bureaucratic bodies of the state where the state is strong, and of the anti-state where the state is weak. Sturzo's fear was that "one day today's powercentralizing state will collapse even with its half-chained freedom, and there the anti-state, itself a powercentralizing entity, will rise to power with the cadaver of political freedom at its feet" (Sturzo 1958-1998b, p.278). According to Sturzo, by subverting the rights inherent in human beings, statism also subverts the powers and functions of the administration, producing an economic imbalance in the production and distribution of goods and services, due to its irrational initiatives, elevated costs, and management deficit.

Sturzo's lesson in economics can be traced back to the maxim, which is typically used in the ordoliberal context, "the state, a referee, and not a player in the free economic game." Palladino, the Italian economist executor of the Italian Popular Party ${ }^{11}$ who was one of

10 "A State-controlled organisation on subsidiarity puts up for discussion not only the repartition of competence and power between the various institutional levels, from local to European levels, but also puts up for discussion the repartition of competences in the horizontal sense, between operators having diverse characteristics - public, private and State-private - having in common the capability to carry out activities of general interest. This problem has already been addressed in different and in convergent ways applying a variety of theories, with the most important identifiable as federalism, the theory of subsidiarity and the model of Social Market Economy. These different approaches allow one to understand the various elements of the historical process. Their capacity to develop a cross-fertilization process can be attributed to the very nature of the ongoing processes involving the change referred to by all the three mentioned" (Velo 2014, p.15).

11 The Italian Popular Party was found by Sturzo on January 18, 1919, and in the opinion of the Italian historian Chabod, it was "the most notable event in the history of the Italian 20th century." It contributed to the end of the so-called "Roman question," exacerbated by the capture of Rome by the Italian army on September 20, 1870 (Chabod, 1961, p.43). An interesting international acknowledgment about the role played by Sturzo, before and during the Second World War, comes from an article written by Moos (1945), published on "The American Political Science Review": "Sturzo's fairness and objectivity have won for him the praise of such diverse scholars as Vilfredo Pareto, Gaetano Salvemini, and G.A. Borgese. Because of his integrity, the recent appeals that Sturzo be not overlooked for a reconstruction assignment in occasioned no surprise" Moos (1945, pp.291-292). the men closest to him in the last years of his life, has the merit of having highlighted Don Luigi Sturzo's lesson in economics. Palladino wrote in a volume dedicated to the US recessions from 1927 to 1957, "In rethinking the past and recent economic and financial experience, we shall make reference above all to the critical position assumed by Don Luigi Sturzo in the face of more relevant government and parliamentary directions on the topic of the state intervention on the topic of state intervention in the economy" (Palladino 1958, p.171). We are especially indebted to Palladino who received Sturzo's thought with a strong commitment to understanding national and international economic processes and to reflecting answers consistent with Sturzo's sociological presuppositions and oriented toward the current of research defined as ordoliberalism. Sturzo was aware that "stability" - understood as full commitment - and "development" in the absence of inflation represent two demands of modern democracies, as they are more sensitive to market needs. Their greater market sensibility results from diminished derivations from social protection typical of archaic societies; consequently, women and men of the postwar period were much freer, but at the same time much more exposed to risks related to possible economic crises and catastrophes.

Consistent with the ordoliberal lesson, Palladino emphasized the Sturzonian principle of "the sociology of the concrete" regarding the evils of statism, "since the series of economic and social relationships in a free society is always posed as a question of fair and proper competition, it is well to observe that the following principle of free competition was suffocated yesterday (in the past) by the illusion of being able to consider the market the playing field and referee of the economic game, and is more seriously threatened today by the error of deeming the state a party and referee of the game itself. And thus the game remains a confused one, and its stability enters into conflict with the ulterior development of the economy" (Palladino 1958, p.178). Ultimately, Sturzonian teaching, mediated by Palladino's contribution, was received in Italy in the form of a metaphor: the market was understood as a game or match where the best result is obtained when three conditions exist: the presence of good players (conscious and updated economic workers), clear and certain rules (principles with which to regulate the hierarchy of interests and ends, starting from those individuals and of groups, of the categories and - in the universal sphere - of the individual nations), and an impartial referee.

The first interpretational error is in considering the market as the playing field, in which senseless automatons with homogeneous - and thus indifferent - expectations exercised themselves in the public manifestation 
of the principle of free and perfect competition. This dual function was motivated by the conviction that it was sufficient for the state to serve as the guarantor of economic freedom, and consequently, to stop anyone from disrupting competition - which, on its own, was imperfect - as an interpretation of the "invisible hand" such that instances of individual selfishness would be directed toward the "greatest common good." This mistake, according to Palladino, gave rise to the fallacious idea that universal and free competition would regulate the natural and spontaneous circulation of work, capital, and goods, resolving the global problem of allocation of scarce resources. Palladino highlighted that when the "healthy force of the economy's sure development" (which has historically been termed selfishness) is not moderated by reason, it cannot serve as a brake or limit. In this way, by exploiting the increased revenues of the larger companies, the "selfishness" ended up having the upper over the weakest ones, "as companies have grown in proportion they have also become less numerous in the main sectors of the economy: the iron and steel industry, metallurgy, sources of energy, mechanics, credit, etc. In this way individual selfishness has often become group selfishness (monopolies, trusts, cartels), class selfishness (trade union monopolies) and national selfishness (economic imperialism and isolationism)" (Palladino 1958, p.179).

At the end of the 1950's it was evident that the great economic and social question was moving towards the search for an arbiter able to guide the economic game, aware of the inability of the market to self-regulate and the worst damages that would have produced the state if was placed at the same time as an arbiter and player, was being directed toward the search for a referee that could guide the economic game. People began to understand how anti-monopoly and antitrust laws would not suffice, as these sectors were already dominated by a few companies: no law would prevent directors from collaboratively making decisions intended to influence the global market for a good. Palladino saw three possible remedies: having set fairness and stability as objectives of the economic game led by free men, he considered that these objectives could be pursued as long as society addressed the quality of economic players, assumed full consciousness of its individual and collective goals, and became definitively aware that only the principle of free competition "is compatible with the economic game of a free society founded on the incentive of private property, on men's free individual choices, and on the democratic method as workers, consumers, and savers" (Palladino 1958, p.181). Instead, where economic power is confused with political power on the international field, controlled by nations, or worse, through a mixed economic system in the domestic realm, it is highly unlikely the results would be any more comforting than those of an economy left unto itself, since the asphyxiating control of the entrepreneurial state would lead to an increasing confusion of the political and economic system.

\section{Conclusions}

In this paper, the author tried to highlight contributions of Sturzo which are relevant to the historical debate on civil society. In Sturzo's opinion, civil society represents special context or habitat in which one can express an ethics that illuminates a free, sympathetic, and responsible act. This model rejects state intervention to build a "just society," because it is committed to emphasizing the freedom of all sovereign citizens who can organize themselves into intermediate bodies and, in this way, promote a "free and virtuous society."

Civil society, therefore, should identify those social relationships that definitively refer to the values of dignity of the human person and her/his rights as a free and responsible subject. Consequently, civil society should encourage political, economic, and cultural relationships that maximize humanity. The polyphony of this kind of civil society allows it to respond adequately to the wide dimensional range of the free expression of personality.

Moreover, Sturzo's civil society first requires the exercise of civic virtues that could be synthesized with self-government: consider the set of virtues marking the distance between the subject, folded on itself and at the mercy of coercive power (pray, pay, obey), and the sovereign who is responsible for his actions and is therefore free to contribute to the realization of his personality. The exercise of these virtues requires constant sacrifice and perpetual vigilance, as the project of civil society is not the intentional outcome of some clever social scientist. Sturzo's civil society is not a work of social engineering that has been reached definitively. On the contrary, it is the slow evolution of attitudes that have received its historical form (institutions) after an unending - never definitively accomplished - work of approximation performed by imperfect men.

Ultimately, what does exist is a civil society in which the state and market operate in their own field. The state sets the rules, enforces the market (companies, cooperatives, voluntary sector, etc.), and expresses the vitality and spontaneity of the citizens within the constitutional framework described by the political order. This is the SME, and we believe that this theoretical perspective successfully expresses the Christian idea of civil society and the common good.

In returning to the starting point and concluding, we affirm that if a greater involvement of civil society simply means "adding a seat at the table," then we would 
always operate in the corporatist logic of those who interpret the civil as a form of institutional pluralism, that is, ordered hierarchically from the state. Rather, Popper and Sturzo believed that the rational action is not to ask "who should rule," but to answer this question entirely consistent with the classical liberal and ordoliberal tradition - how can we check on who is in charge?

\section{References}

Antiseri D., La Vienna di Popper, Soveria Mannelli, 2000.

Antiseri D., Karl Popper, Soveria Mannelli, 2011.

Antonetti N., Luigi Sturzo e la costituzione italiana, Soveria Mannelli, 2017.

Böhm F., Eucken W., Grossmann-Dörth H., The Manifesto of 1936, In: Peacock A., Willgerodt H. (Eds.), Germany's social market economy: origins and evolution, London, 15-26, 1936/1989.

Buttiglione R., Metafisica della conoscenza e politica in S. Tommaso d'Aquino, Forlì, 1985.

Cappellano M., Società civile, In: Cappellano M. (Ed.), Lessico sturziano, Soveria Mannelli, 930-933, 2013.

Chabod F., L'Italia contemporanea (1918-1948), Torino, 1961.

Dahl R.A., Poliarchy: participation and opposition, New Haven, Connecticut, 1971.

De Rosa G., Luigi Sturzo, Turin, 1977.

Di lorio F., Cognitive autonomy and methodological individualism: the interpretative foundations of social life, Berlin and New York, 2015.

Di Lascia A., Don Luigi Sturzo-Christian Democrat, Am Polit Sci Rev, 49, 269-292, 1945.

Di Nuoscio E., Philosophy of the social sciences, Oxford, in press.

Donati P., Alla Ricerca di una società civile. Che cosa dobbiamo fare per aumentare la capacità di civilizzazione del paese? In: Donati P. (Ed.), La società civile in Italia, Milano, 21-80, 1997.

Edwards M., Civil society and the geometry of human relation, In: Edwards M. (Ed.), The oxford handbook of civil society, Oxford, 3-14, 2011.

Efficace A., Economia e società nel pensiero di don Luigi Sturzo, In: Guccione E. (Ed.), Luigi Sturzo e la democrazia nella prospettiva del terzo millennio, Firenze, 501-550, 2004.

Ehrenberg J., The history of civil society ideas, In: Edwards M. (Ed.), The oxford handbook of civil society, Oxford, 15-25, 2011.

Farrell-Vinay G., The London exile of Don Luigi Sturzo (1924-1940), Heythrop J, 45, 158-177, 2004.
Popper asked, "How can we so organize political institutions that bad or incompetent rulers can be prevented from doing too much damage?" (Popper 1966, p.126). It would seem that this is the most significant question in an open society, populated by fallible, but perfectible people, desirous of promoting institutional conditions of the common good.

Felice F., The ethical foundations of market economy: reflections on the economic personalism in Luigi Sturzo, Mark Morality, 4, 217-239, 2001.

Felice F., L'economia sociale di mercato, Soveria Mannelli, 2008.

Forte F., Felice F., Il liberalismo delle regole, Genesi ed eredità dell'economia sociale di mercato, Soveria Mannelli, 2016.

Forte F., Felice F., Forte C., L'economia sociale di mercato e i suoi nemici, Soveria Mannelli, 2012.

Koslowski P., Politik und Ökonomie bei Aristoteles, München, 1976.

Koslowski P., La società civile nell'epoca postmoderna, In: Donati P., de Kerckove D., Alexander J.C. (Eds.), La società civile alla fine del XX secolo, Bologna, 45-82, 1997.

Liermann C., La Germania nella vosione di Luigi Sturzo, In: Guccione E. (Ed.), Luigi Sturzo e la democrazia nella prospettiva del terzo millennio, Firenze, 255285, 2004.

Moos M., Don Luigi Sturzo - Christian Democrat, Am Polit Sci Rev, 39, 269-292, 1945.

Palladino G., La Recessione Economica Americana, Roma, 1958.

Palladino G., Don Sturzo Oggi, Napoli, 1995.

Pastori P., La nozione di "società civile in Luigi Sturzo, In: Guccione E. (Ed.), Luigi Sturzo e la democrazia nella prospettiva del terzo millennio, Firenze, 753858, 2004.

Pollock R.C., Luigi Sturzo: an anthology of his writings, Thought, 28, 165-208, 1953.

Popper K.R., The open society and its enemies V I-II, Princeton, 1966.

Ricci C., Non conta proprio nulla che la nostra infanzia abbia respirato l'aria dell'Aventino? In: Giardina A. (Ed.), Storia Mondiale d'Italia, Roma, 140-144, 2017.

Shearmur J., The political thought of Karl Popper, New York, 1996.

Sturzo L., The inner laws of society, New York, 1944.

Sturzo L., Paura della libertà, "Il Giornale d'Italia", December 29, 1957, In: Argiolas C. (Ed.), Politica 
di Questi Anni. Consensi e Critiche, Roma, 14, 156-159, 1998a.

Sturzo L., Ceti piccoli e statalismo, "Il Giornale d'Italia, In: Argiolas C. (Ed.), Politica di Questi Anni. Consensi e Critiche, Roma, 14, 276-278, 1998b.

Sturzo L., Lo Stato corporativo, in "La Terre Wallonne", Bruxelles, luglio 1933, today in Id., Del metodo sociologico (1950). Studi e polemiche di sociologia 1933-1958, Zanichelli, Bologna, pp. 103-118, 1970a.

Sturzo L., Lo corporazione moderna, in "El Mati", BarcelIona, aprile 1934, today in Id., Del metodo sociologico (1950). Studi e polemiche di sociologia 1933-1958, Zanichelli, Bologna, pp. 137-152, 1970b.

Suardo Secco D., I Cattolici Intransigenti. Studio di una Psicologia e di una Mentalità, Brescia, 1962.

Suppa S., Fra società organica e società aperta: note su fondamenti e motivazioni della risposta di Luigi Sturzo, In: Guccione E. (Ed.), Luigi Sturzo e la democrazia nella prospettiva del terzo millennio, Firenze, 713-731, 2004.
Timasheff S.N., The sociology of Luigi Sturzo, Baltimore, 1962.

Tocqueville A.D., [1835-1840], democracy in America, New York, 1969.

Todisco E., L'impero come comunità di cittadini, In: Giardina A. (Ed.), Storia Mondiale d'Italia, Roma, 153157, 2017.

Vasale C., Democrazia e pluralismo nella sociologia storicistica di Luigi Sturzo, Roma, 1975.

Vasale C., Cattolicesimo politico e mondo "moderno", Società, politica, religione in Luigi Sturzo, Milano, 1988.

Velo D., Social market economy and the future of European Unification, In: Gil-Robles J.M., De Quadros F., Velo D. (Eds.), The European union and the social market economy, Bari, 3-32, 2014.

Walzer M., The idea of civil society: a path to social reconstruction, In: Dionne E.J. (Ed.), Community works: the revival of civil society in America, Washington, DC, 123-144, 1998. 
